\title{
Monomicrobial necrotising soft tissue infection of the hand caused by a Panton-Valentine leukocidin- negative Staphylococcus aureus strain in a 66-year- old patient with diabetes
}

\author{
Caroline Furnon, ${ }^{1}$ Florence Ader, ${ }^{1,2}$ Tristan Ferry, ${ }^{1,2}$ Anne Conrad ${ }^{1,2}$
}

${ }^{1}$ Service de Maladies Infectieuses et Tropicales, Hospices Civils de Lyon, Hôpital de la Croix Rousse, Lyon, France ${ }^{2}$ INSERM U1111, Centre International de Recherche en Infectiologie, Université Claude Bernard Lyon 1, Lyon, France

Correspondence to Dr Tristan Ferry,

tristan.ferry@univ-lyon1.fr

Accepted 18 December 2018

\section{DESCRIPTION}

A 66-years-old man, with a history of poorly monitored type 2 diabetes was admitted to the emergency room because of general weakness. At admission, he was hypothermic at $34^{\circ} \mathrm{C}$, with stable haemodynamic and neurological status. Clinical examination revealed erythematous swelling of the back of the right hand that had appeared 2 days earlier according to the patient, without any history of trauma or injury. Laboratory tests showed diabetic ketoacidosis, a haemoglobin A1c level at $12 \%$ as well as a biological inflammatory syndrome with $\mathrm{C}$ reactive protein plasmatic level at $360 \mathrm{mg} / \mathrm{L}$ and hyperleucocytosis with a neutrophil count at 28 giga/L. Insulin therapy and intravenous amoxicillin-clavulanate were started. Right-hand injury worsened over 48 hours, with the formation of necrotic areas and secretory wounds on the back of the right hand (figure 1A). In parallel, he developed monarthritis of the right knee. Urgent surgical debridement of the right hand was performed with large excision of necrotic skin and subcutaneous tissues (figure 1B), subsequent tenosynovectomy of extensor tendons and abundant washing (figure 1C). Admission blood cultures and intraoperative samples recovered a methicillin-sensitive Staphylococcus aureus (S. aureus). Antibiotic treatment was switched to intravenous cefazolin, single-dose gentamicin and oral ofloxacin for 4 weeks and finally switched to oral rifampin and ofloxacin, with a total duration of antibiotic treatment of 6 weeks. Six surgeries over 2 weeks were required to clear the right hand. Subsequent wound care required a Negative Pressure Wound Therapy System (VAC), followed by the application of a dermal regeneration template (INTEGRA membrane). Finally, a skin graft was performed 3 weeks later. Persisting septic arthritis despite appropriate antibiotic treatment required surgical joint drainage by arthrotomy of the right knee, yielding the same $S$. aureus. Toxin gene profiling of the $S$. aureus strain revealed the presence of the enterotoxin gene cluster egc but did not show the evidence for the lukPV locus encoding the Panton-Valentine leukocidin (PVL). There were no other secondary septic foci and cardiac echography did not show any signs of endocarditis. Patient's general condition improved and 4 months after discontinuation of antibiotic treatment, he progressively regained use of his right hand (figure 1D).

Necrotising skin and soft tissue infections (SSTIs), rapidly spreading infections which may extend from the skin to the musculature, are responsible for high mortality and morbidity. ${ }^{1}$ The most common comorbid condition consists of diabetes mellitus. ${ }^{2}$ Necrotising SSTIs mostly result from polymicrobial synergistic infections, especially caused by streptococci, S. aureus, enterobacteriaeceae and anaerobes. Group-A streptococcus is the most common cause of monomicrobial necrotising SSTIs, and SpeB is a crucial virulence factor that facilitates tissue invasion. ${ }^{1}$ The present case is of particular interest as it was a
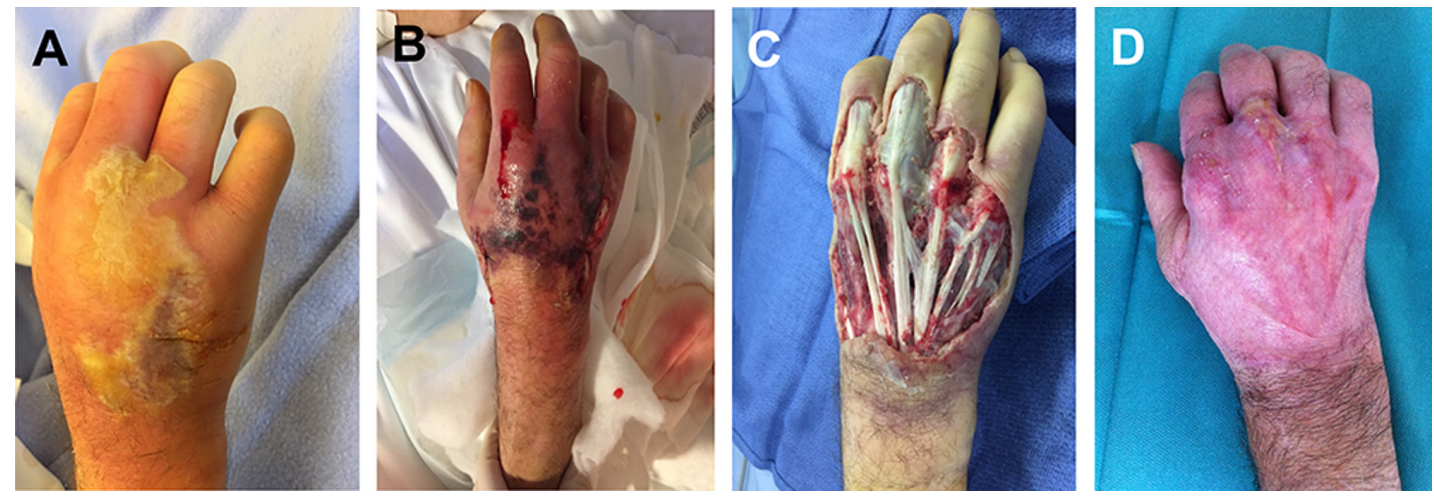

Figure 1 Necrotising skin and soft tissue infection of the back of the right hand caused by methicillin-susceptible PVL-negative Staphylococcus aureus. Appearance before (A) and after (B) surgical debridement, after tenosynovectomy of extensor tendons (C) and 4 months after a skin graft was performed (D). PVL, Panton-Valentine leukocidin. 
monomicrobial S. aureus-associated necrotising SSTI, due to a PVL-negative strain. $S$. aureus alone could be responsible for necrotising SSTIs, but in the cases reported in the literature, the strains usually harboured the genes encoding the PVL. This toxin is a pore-forming toxin that has the ability to induce skin necrosis in animal models and is usually involved in patients with furunculosis. ${ }^{3}$ Based on the case presented here, PVL-negative $S$. aureus could be involved in monomicrobial necrotising SSTIs. As described in other patients with necrotising SSTIs, diabetes is probably a major risk factor, and aggressive surgical

\section{Learning points}

Staphylococcus aureus is an uncommon cause of monomicrobial necrotising skin and soft tissue infections (SSTIs), and is considered to be associated with PantonValentine leukocidin (PVL) production.

- Nevertheless, PVL-negative $S$. aureus could also be responsible for monomicrobial necrotising SSTI, especially in patients with diabetes mellitus.

- Management of monobacterial necrotising SSTIs includes aggressive surgical debridement and antibiotherapy. debridement done in an emergency is the cornerstone of the treatment. $^{1}$

Acknowledgements The authors would like to acknowledge the French National Reference Center for Staphylococci for strain characterisation and they gratefully acknowledge Dr Thomas Castel, orthopaedic surgeon, who participated to the patient care.

Contributors All authors participated to the patient care. CF: wrote the this draft all the manuscript. FA, TF and AC: significantly contributed to the improvement of the manuscript. TF: involved in French National Recommendation for the management of skin and soft tissue infection.

Funding The authors have not declared a specific grant for this research from any funding agency in the public, commercial or not-for-profit sectors.

Competing interests None declared.

Patient consent Obtained.

\section{REFERENCES}

1 Stevens DL, Bryant AE. Necrotizing Soft-Tissue Infections. N Engl J Med 2017:377:2253-65

2 Wong $\mathrm{CH}$, Chang $\mathrm{HC}$, Pasupathy S, et al. Necrotizing fasciitis: clinical presentation, microbiology, and determinants of mortality. J Bone Joint Surg Am 2003;85A:1454-60.

3 Shallcross LJ, Fragaszy E, Johnson AM, et al. The role of the Panton-Valentine leucocidin toxin in staphylococcal disease: a systematic review and meta-analysis. Lancet Infect Dis 2013;13:43-54

Copyright 2018 BMJ Publishing Group. All rights reserved. For permission to reuse any of this content visit https://www.bmj.com/company/products-services/rights-and-licensing/permissions/

BMJ Case Report Fellows may re-use this article for personal use and teaching without any further permission.

Become a Fellow of BMJ Case Reports today and you can:

- Submit as many cases as you like

- Enjoy fast sympathetic peer review and rapid publication of accepted articles

- Access all the published articles

- Re-use any of the published material for personal use and teaching without further permission

For information on Institutional Fellowships contact consortiasales@bmjgroup.com

Visit casereports.bmj.com for more articles like this and to become a Fellow 